\title{
The snowball effect
}

\section{Planning for preservation infrastructure in a small library}

mall libraries frequently face significant chal-
lenges related to funding and staff capacity when attempting to complete large projects and improve infrastructure. With careful planning and a bit of luck, however, it is possible to leverage small successes into much larger accomplishments. The University of Arizona Poetry Center, a special collections library of contemporary poetry within the College of Humanities at the University of Arizona, recently adopted this approach to implement a systematic overhaul of its preservation program.

With three library staff and roughly 50,000 books South view of the University of Arizona Poetry Center. Photo by in its physical Robert Reck, 2007. collections, the

Poetry Center is a relatively small institution, lacking both the funding and the staff capacity to attempt larger infrastructure projects as a routine matter. Yet since 2014, the Poetry Center has completed a series of major preservation initiatives requiring specialized labor, large equipment purchases, and substantial expenditure. This case study will show how the Poetry Center translated a \$6,000 Preservation Assistance for Smaller Institutions grant from the National Endowment for the Humanities (NEH) into a multiyear preservation campaign, which has attracted more than $\$ 1$ million in funding from private and public sources.

\section{Background}

The Poetry Center was established in 1960 to "maintain and cherish the spirit of poetry," in the words of founder Ruth Walgreen Stephan. Beginning with just a few hundred volumes of poetry donated from Stephan's personal collection, the Poetry Center has grown to become one of the major contemporary poetry collections in North A m e r i c a, housing more than 80,000 materials related to poetry (including books, photographs of poets, broadside printings of poems, and recordings of poets reading their work in the institution's long-running Reading Series). After residing in a series of small cottages near the University of Arizona campus for de-

Sarah Kortemeier is associate librarian and library director at the University of Arizona Poetry Center, email: ssk@email.arizona.edu

() 2021 Sarah Kortemeier 
cades, fundraising began in the 1990s to house the Poetry Center's programs and collections in a custom-built, dedicated structure.

The Poetry Center moved into its permanent home, the Helen S. Schaefer Building, in 2007. Designed by Tucson architectural firm Line and Space, this landmark, award-winning building now hosts more than 10,000 visitors each year. The Helen S. Schaefer Building features an open-stack Reading Room lit by a dramatic two-story wall of east-facing glass windows. The building also includes a climate-controlled vault for rare books and a closed-stack Archives Room, which houses institutional records as well as older and more fragile books from the main collection. The completion of the Helen S. Schaefer Building, which created institutional capacity for both open- and closed-stack storage, dramatically improved the Poetry Center's ability to preserve its nationally significant humanities collections.

$\mathrm{D}$ e spite these advances, however, a series of preservationrelated problems occurred in the new building d u r i n g

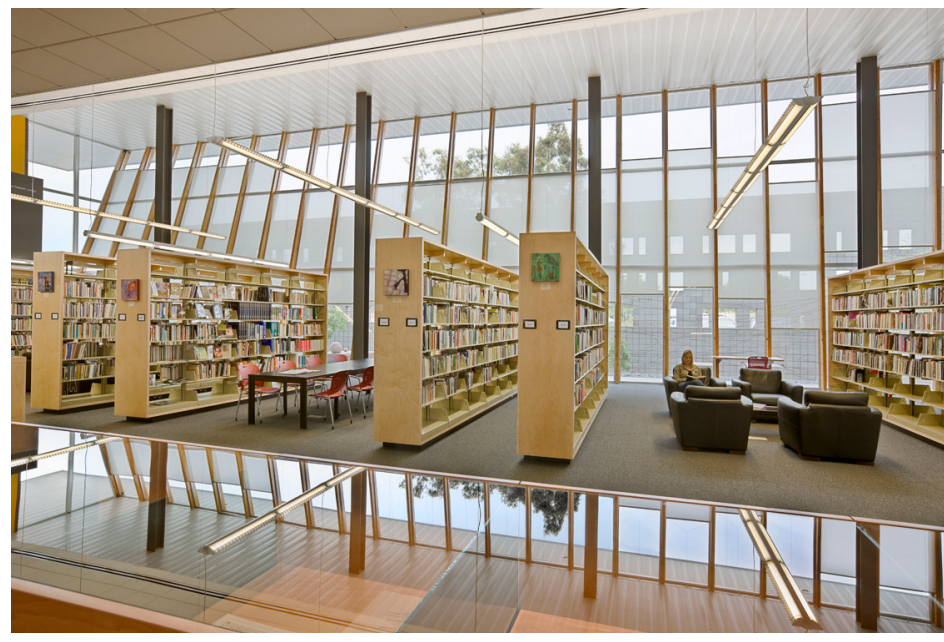

s u m m e r Interior shot of the library. Photo by Robert Reck, 2007.

20011 ,

demonstrating the need for an audit of existing preservation measures. That year, temperatures dropped and relative humidity soared in the rare book vault during Arizona's summer monsoon season. During the monsoon, which generally happens during July and August in southern Arizona, relative humidity can increase by $30 \%$ or more indoors, a seasonal fluctuation large enough to become an annual preservation concern. ${ }^{1}$ On a muggy day in July 2011 , a library volunteer reported that the vault felt abnormally cold. Staff investigated climactic conditions and discovered temperatures below 65 degrees Fahrenheit and RH levels exceeding 60\% (the vault is normally kept at 68 degrees Fahrenheit and $30-40 \% \mathrm{RH})$. Library staff were forced to deploy a portable dehumidifier in the rare book vault as an emergency mitigation measure until a problem with the vault's HVAC system could be repaired.

This experience led then-Library Director Wendy Burk to seek a comprehensive preservation assessment from an independent consultant, so that the Poetry Center could assess and improve its preservation practices. To pay the consultant's fees, Burk applied to NEH's Preservation Assistance Grants for Smaller Institutions grant program. The grants funded through this program "help small and mid-sized institutions ... improve their ability to preserve and care for their significant humanities collections." ${ }^{2}$

Applicants are required to "draw o n th e knowledge of consultants" a n d to "choose a conservator whose specialty is appropriate for the nature of their collections." 3

In essence, the NEH's Preservation Assistance Grants for Smaller Institutions help small libraries without full-time conservators (like the Poetry Center) enlist expert help with specialized preservation concerns. These grants can be powerful catalysts for major improvements in small libraries' preservation programs, as the Poetry Center's experience demonstrates.

Burk worked with internationally recognized consultant Randy Silverman, preservation 
librarian at the University of Utah's Marriott Library, to design a Preservation Assessment for the Poetry Center. The NEH funded this grant in 2013, and Silverman conducted his assessment the following spring.

\section{The preservation program}

The Preservation Planning Study Silverman produced as a result of his 2014 assessment provided the Poetry Center with a roadmap for the next five years, guiding improvements in both preservation practices and the library's infrastructure.

On Silverman's advice, the Poetry Center "started small," working first on lowcost initiatives (like rehousing broadsides in protective Mylar) and writing follow-up grant applications for inexpensive improvements. For example, in 2015 Burk wrote a successful follow-up grant to NEH for small equipment purchases,

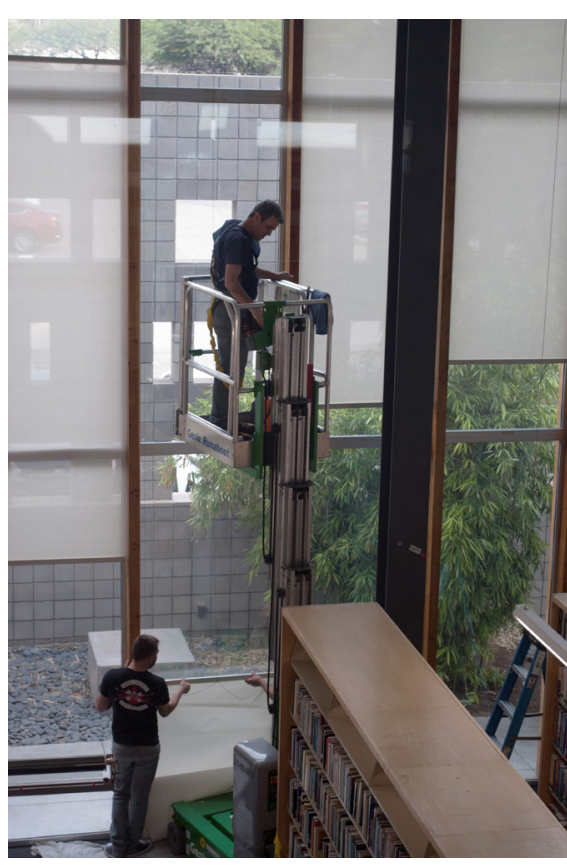

Workers applying UV-filtering film on the Poetry Center's big bank of windows. Photo by Sarah Kortemeier. including a museum-grade vacuum cleaner and a hand-held environmental monitor. Burk also used the recommendations in the Preservation Planning Study to successfully advocate for the addition of 1.0 FTE to the library staff, significantly expanding staff capacity for preservation work.

Over the course of the next five years, the library staff gradually worked up through Silverman's list of recommendations in order of ascending project cost. This strategy allowed the Poetry Center's staff to cite early successes in its preservation program, as well as Silverman's expert opinion, when the time came to ask for larger funding commitments. The Preservation Planning Study provided the Poetry Center with a clear and highly actionable set of goals, which made its entire preservation program possible thereafter.

The first major preservation project the Poetry Center undertook as a result of Silverman's assessment came in 2017, when the library staff secured funding to mitigate light levels in the main part of the Helen S. Schaefer Building. During his 2014 assessment, Silverman discovered that the two-story wall of windows that light the Poetry Center's Reading Room were allowing visible and UV light radiation into the room at rates that far exceeded recommended limits for collection storage and work areas. Silverman referred to this situation as "untenable" and existing light levels as "excessive," recommending that the Poetry Center take immediate action to reduce light levels in its reading room.

The Poetry Center applied to several grantmakers for funding to cover the Reading Room windows with light-filtering film, ultimately winning funding for this project from the Southwestern Foundation for Education and Historical Preservation.

Completion of this urgent priority lent energy to a major fundraising initiative in the Poetry Center Library. In 2018, the library launched a campaign to create a $\$ 500,000$ endowment for rare book acquisitions through private donations. The library's success in its preservation program was a major factor in the success of this effort: staff were able to demonstrate to donors that valuable new acquisitions would be cared for using industry-standard best practices and considerable institutional investments of time and money. The Poetry Center reached its fundraising goal for the rare book endowment a mere two years after launching this campaign. In this way, the public funding provided by the relatively small NEH Preservation Assistance 
for Smaller Institutions grant translated to significant fundraising opportunities in both preservation and collection development.

In 2018, Burk left the Poetry Center, but library staff continued to work on the preservation campaign she had set in motion. As the newly appointed library director, I lead the Poetry Center Library with concluding its preservation program in 2019-2020 with the two most expensive projects in the Preservation Planning Study: the installation of high-density mobile shelving in the institution's Archives Room, and the purchase of museum-grade exhibition cases for the Poetry Center's gallery space.

Funding for the museum cases was raised from private donors who shared the Poetry Center's desire to make materials purchased with rare book endowment funds accessible to all in public exhibitions. Once again, the Poetry Center was able to build on a previous successful effort (in this case, the

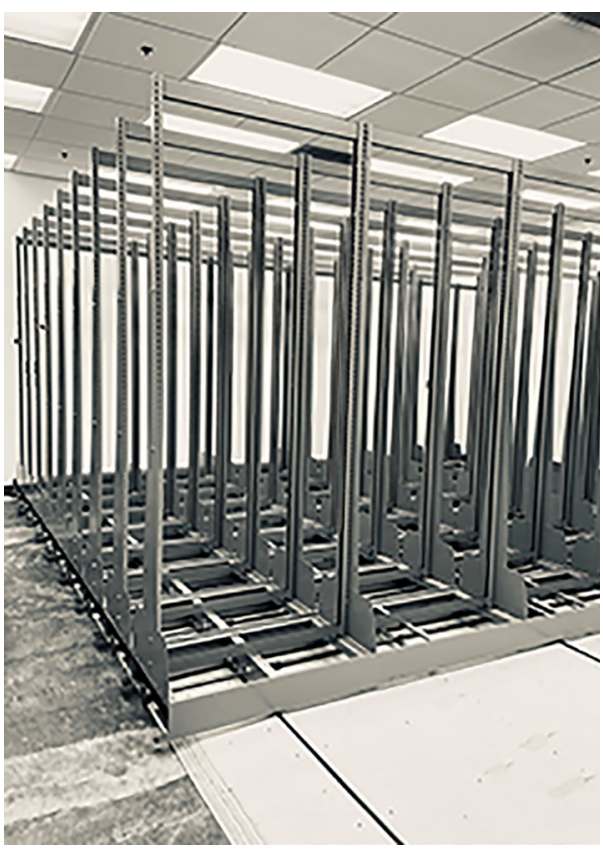

The Poetry Center's compact shelving project midway through installation. Photo by Sarah Kortemeier. raising of funds for a rare book endowment) to achieve a new fundraising goal. The Poetry Center is in the process of ordering new display cases from the internationally recognized German company CaseWerks. These cases will be ready to use when the library is able to reopen after the COVID-19 pandemic.

For the installation of high-density mobile shelving, the Poetry Center relied on partnerships and support from a variety of sources: this project presented logistical as well as fiscal challenges. In order to install a compact shelving system in the Archives Room, the room had to be assessed (in terms of floor strength) for suitability, then emptied of all its collections and shelving, and collections had to be shifted out in shelf order, so that they could be reshelved later with a minimum of error. The Poetry Center has no staff with expertise in these areas but was fortunately able to draw on the experience of colleagues in the University's Main Library, who generously donated staff time to the Poetry Center for this project. With this assistance from the Main Library, and with the recommendations laid out in the Preservation Planning Study, the Poetry Center applied successfully to the NEH's Sustaining Cultural Heritage Collections grant program for the cost of the shelving.

During the installation process, which took place during the break between the fall and spring semesters to minimize disruption for patrons, the Poetry Center library staff relied much on the expertise of colleagues in the Main Library. The libraries teams were able to complete collections shifting efficiently, and their existing relationships with the University's Facilities Management department proved invaluable in overcoming logistical hurdles. (For example, the libraries teams discovered that the existing carpeting in the Archives Room, which had lain under thousands of pounds of books for a decade, could not be removed with hand tools. They connected the Poetry Center with a member of the Facilities floor team who had access to the right equipment and was willing to clock overtime hours on the Saturday before Christmas to get the job done.)

The Poetry Center was able to install compact shelving over a four-week period in December 2019-January 2020-a feat that would never have been possible without the assistance of experienced colleagues at the Main Library and the generous financial support of $\mathrm{NEH}$. 


\section{Conclusion}

The Poetry Center's five-year preservation campaign has enjoyed remarkable success due to a series of crucial partnerships and careful planning, beginning with the NEH-funded Preservation Assessment in 2014 and culminating with major improvements to infrastructure. The steps laid out in Randy Silverman's Preservation Planning Study have now been completed, having attracted funding totaling more than $\$ 1$ million from public and private sources. The Poetry Center thanks $\mathrm{NEH}$, the Southwestern Foundation for Education and Historical Preservation, Randy Silverman, our colleagues in the University of Arizona Libraries and Facilities Management, and our donors, for the support that has made these accomplishments possible.

Note: Any views, findings, conclusions, or recommendations expressed in this article do not necessarily represent those of the National Endowment for the Humanities.

\section{Notes}

1. See the Northeast Document Conservation Center's excellent series of preservation leaflets for more information about the damaging potential of fluctuations in temperature and RH. Of particular interest: "2.1: Temperature, Relative Humidity, Light, and Air Quality: Basic Guidelines for Preservation," Northeast Document Conservation Center, accessed October 20, 2020, https://www. nedcc.org/free-resources/preservation-leaflets/2. - the-environment/2.1-temperature, -relative-humidity,-light,-and-air-quality-basic -guidelines-for-preservation.

2. Division of Preservation and Access, "Preservation Assistance Grants for Smaller Institutions," National Endowment for the Humanities, accessed October 1, 2020, https://www.neh.gov /grants/preservation/preservation-assistance -grants-smaller-institutions.

3. Ibid. 2

("Catalyzing research ...," continued from page 227)

for the survival of communities of knowledge for generations to come.

\section{Notes}

1. "Christine Walde," University of Victoria Libraries, University of Victoria, 2020, accessed November 23, 2020, https://www.uvic.ca/library /research/librarians/cwalde/index.php.

2. "Linked Modernisms," University of Victoria, accessed November 23, 2020, http://linkedmods.uvic.ca/.

3. Shailoo Bedi, and Christine Walde, "Transforming Roles: Canadian Academic Librarians Embedded in Faculty Research Projects," College \& Research Libraries 78, no. 3 (2017): 314, accessed November 23, 2020, https://doi.org/10.5860 /crl.78.3.314.

4. Constance Crompton, Richard J. Lane 1966, and Raymond George Siemens 1966, Doing More Digital Humanities (London; New York, NY: Routledge/Taylor \& Francis Group, 2020).

5. "Moving Trans History Forward 2021," University of Victoria, 2020, accessed November 23, 2020, https://www.uvic.ca/mthf2021/.

6. "The British Colonist," University of Victoria Libraries, 2020, accessed November 23, 2020, http://www.britishcolonist.ca/.
7. "Colonial Despatches: The colonial despatches of Vancouver Island and British Columbia 1846-1871," University of Victoria, accessed November 23, 2020, https://bcgenesis.uvic.ca/.

8. "Ian McTaggart Cowan: Champion of Canadian Ecology," University of Victoria Libraries, accessed November 23, 2020, https://exhibits. library.uvic.ca/spotlight/ian-mctaggart-cowan.

9. "Library Services for Grant-funded Research Projects," University of Victoria Libraries, accessed November 23, 2020, https://www.uvic. ca/library/about/ul/grants/.

10. "Narrative Art and Visual Storytelling in Holocaust and Human Rights Education," University of Victoria, accessed November 23, 2020, http://holocaustgraphicnovels.org/.

11. Matt Huculak, "Ravensbrück Visual Storytelling Colloquium and Workshop," University of Victoria Libraries, 2020, accessed November 23, 2020, https://www.uvic.ca/library/home/ home/news/current/embedded-librarianship.php.

12."Competencies for Librarians in Canadian Research Libraries," Canadian Association of Research Libraries, 2020, accessed November 23, 2020, https://www.carl-abrc.ca/wp-content /uploads/2020/09/Competencies-Final-EN-1-2.pdf. $\approx 2$ 